Laura Wright, University of Cambridge

\title{
On Non-Integrated Vocabulary in the Mixed-Language Accounts of St Paul's Cathedral, 1315-1405
}

This chapter investigates the role of unintegrated English and French vocabulary in the mixed-language Latin-matrix accounts of St Paul's Cathedral, written in London between 1315 and 1405. 'Integrated' and 'non-integrated' means whether or not an English or French word had a Latin grammatical suffix, as sometimes they did and sometimes they didn't. The accounts were kept by rentcollectors for the Cathedral, and passages containing phrases and clauses (as opposed to lists of people's names, addresses and rent) detail repairs to Cathedral property. They are written in a Medieval Latin grammatical matrix, with Latin vocabulary influenced by Anglo-Norman French, and Middle English words positioned in the Noun Phrase. Codeswitching of this sort between Medieval Latin, Anglo-Norman French and Middle English (with sporadic vocabulary from other European vernaculars) was default in accounts written in Britain at this date. ${ }^{1}$ As a generalisation, the matrix language expressed by function words was either monolingual Latin or monolingual Anglo-Norman, with content words in Latin, Anglo-Norman and English placed in modifier, noun, and deverbal -ing slots. The research question asked here is not so much 'why were accounts multilingual', but rather 'why was there any unintegrated element at all in such a highly multilingual text-type?' Given that any word could have been integrated into the Latin matrix by adding a Latin suffix (or an abbreviation or suspension sign representing a Latin suffix), why was a proportion not so integrated? The accounts of St Paul's Cathedral have been chosen for study only because they have not yet been surveyed linguistically, not because they are in any way unusual. On the contrary, their internal linguistic make-up is regular for the date, place and time.

Codeswitching from language to language was one mechanism by which the three languages were mixed in the linguistic system used for accounts and inventories, but it was not the only method. Glossing, cognate roots, visual diamorphs ${ }^{2}$, borrowings and emblems ${ }^{3}$ also facilitated the creation of a multilingual text. However, a proportion of the word-types in the building-accounts of the period studied here almost half - were not integrated into the Latin matrix by these means, be they simplex words, compounds, morphemes or graphies, but rather their 'Englishness'

\footnotetext{
${ }^{1}$ I am particularly grateful to Professor Ian Short, Professor Richard Ingham, Professor David Trotter and the editors for criticism of earlier drafts. See Wright (2012) for a description of the switchpoints.

${ }^{2}$ Visual diamorphs result when two (or more) written codes are overlapped, so that the resultant form is simultaneously both (or all); see Wright (2011: 203).

${ }^{3}$ Emblems are written devices which are not letter-graphs - the ampersand symbol, abbreviation and suspension symbols, and symbols representing pounds, shillings and pence, or weights and measures, for example.
} 
was foregrounded: 〈wr->, <-ck>, <-ght> graph-sequences, for example, had no place in Latin, and although sack was frequently written as <sacc- > (where the hyphen stands for an abbreviation symbol), allowing it to be read as both Latin saccus and English sack, it was also, on occasion, written as <sak>. It begs the question, why was the $\langle-\mathrm{k}\rangle$ spelling-variant retained in this text-type at all? Why did a scribe who wrote $<$ sacc-> on one line, then write $<$ sak $>$ on the next?

In what follows, I briefly describe the mechanics of mixing languages in the St Paul's Cathedral accounts. I report on counting the ratios of integrated multilingual words (that is, words which were simultaneously meaningful and grammatically sufficient in Latin, French and English and combinations thereof), versus monolingual, unintegrated, non-Latin-looking words such as sak, which did not fit the matrix grammatically or orthographically. It transpires that date makes a difference in this archive, with most of the unintegrated material occurring after 1390. I consider the proposition that one purpose of retaining unintegrated matter may have been to differentiate the text-type of accounts from any other text-type. Other text-types incorporated vernacular-language roots too, but without maintaining a proportion of resolutely non-Latinised material (other than personal names and place-names). Business accounts were presented on the page in a unique fashion, both in linguistic construction and mise en page, and could not have been mistaken for anything else. However, this may be imputing too much deliberation to post-1390 developments. The higher ratio of unintegrated matter may have owed more to changes in how AngloNorman, in particular, was learnt in the latter fourteenth century, and not have been consciously determined.

\section{Codeswitching and visual diamorphs}

In accounts and inventories, from those written by the most official public bodies to those of private individuals, codeswitching between Medieval Latin, AngloNorman French and Middle English occurred variably in predictable slots, from the Norman Conquest until the end of the fifteenth century. Certain semantic fields were particularly resistant to representation in Medieval Latin. Names of people, social ranks and titles, place-names, currencies weights and measures, and the names of commodities were often retained in English, Anglo-Norman or other European vernaculars. English usually appeared in the Noun Phrase, with nouns and deverbal -ing forms most frequently switched. In Latin-matrix accounts, a house was usually written as a domus, but also, and especially in compounds, as a hous. A nail was usually written as a clavus, but also, and especially in compounds, as a nayl. The resulting text was, therefore, to some extent glossed, helped by the visual code of abbreviation and suspension symbols which served to both indicate and suppress case-endings, visually paring words to their roots so that they could no longer be assigned to a single language.

Codeswitching is illustrated here with two sets of words, meaning 'gravel' and 'gutter', taken from the building accounts of St Paul's Cathedral, although whether the codeswitched words referred to exactly the same commodity is hard to prove at a distance of nearly seven hundred years. Gravel could come in various sizes, and gutters were made out of wood, lead and tile, potentially giving rise to specialist 
vocabulary. Nevertheless I have only been able to find gravel/zabul- and gutter/stillicidi-/rigoil. $^{4}$

1) It in viij carect de grauell ijs viijd ... It in j carect zabuli iiijd

1400, Dean \& Chapter of St Paul's Cathedral, London, Rental \& Accounts, London Metropolitan Archives, CLC/313/L/D/001/MS25125/040

'And in 8 cartloads of gravel, 2s 8d ... And in 1 cartload of gravel, 4d'

Note that the price is the same, $4 \mathrm{~d}$ per cartload, making it unlikely that the Latin word was used for one sort of gravel and the English word for another. Nos. 2-4 show Medieval Latin stillicidi-, Anglo-Norman and Middle English goter/gutter, and Anglo-Norman rigoil:

2) Itm in bord empt P repacone gutter int domos sci pauli \& Stephi le Blound ijs vjd In merem empt xijd In clau empt iiijd In stipend duoO carpent ibid $P$ duos dies ijs In mudacone $j$ Wag \& $x$ libr plumbi viijd ob ... In quad pua guttera pgent ext ${ }^{a}$ fenestras iijs

1319-20, Dean \& Chapter of St Paul's Cathedral, London, Rental \& Accounts, London Metropolitan Archives, CLC/313/L/D/001/MS25125/1

'And in board bought for repairing the gutter between the houses of St Paul's and Stephen le Blound, $2 \mathrm{~s} 6 \mathrm{~d}$. In timber bought, $12 \mathrm{~d}$. In nails bought, $4 \mathrm{~d}$. In stipend of two carpenters there for two days, $2 \mathrm{~s}$. In cleaning 1 wey and $10 \mathrm{lbs}$ of lead, $81 \frac{1}{2} \mathrm{~d} \ldots$... In purging a certain small gutter outside the windows, $3 \mathrm{~s}$.'

3) Itm ${ }^{9}$ putat soluts thome le plomer $P$ fact ${ }^{u}$ a stillicidioO dce dom ${ }^{9}$ de plubo Pprio iijs vijd ... in plubo empto P stillicidio camini xjd ... In uno plaunk empts $P$ fundo stillicidij iijd ... In plubo empto de thom ${ }^{a}$ plubator P stillicidio came \& $P$ ope suo xis . viijd

1341, Dean \& Chapter of St Paul's Cathedral, London, Rental \& Accounts, London Metropolitan Archives, CLC/313/L/D/001/MS25125/8

'And account paid to Thomas the Plumber for making gutters at the said house from his own lead, $3 \mathrm{~s} 7 \mathrm{~d} \ldots$ in lead bought for guttering of the chimney, $11 \mathrm{~d}$ ... In one plank bought for the bottom of a gutter, $3 \mathrm{~d} \ldots$ in the stipend of one tiler for covering windows and the chimney in the great room ... in lead bought for Thomas the plumber for guttering the room and for his work, 11s $8 d^{\prime}$

4) It in rigoiles \& railles $P$ fenestr ibm viijd

4 The hyphen symbol at the end of the word indicates 'variable case-ending'. I have not invented a Latin nominative singular suffix if one does not occur in the accounts. 
1404, Dean \& Chapter of St Paul's Cathedral, London, Rental \& Accounts, London Metropolitan Archives, CLC/313/L/D/001/MS25125/045

'And in gutters and rails for the windows there, $8 \mathrm{~d}$ '

Gutters occur frequently in building accounts. ${ }^{5}$ In no. 2 the Anglo-Norman word coined from Latin gutta 'drop' + -er takes both a case-ending (in quad pua guttera) and an abbreviation sign ( $P$ repacone gutter), and retains the Latin letter-graph sequence <gutt->. The Anglo-Norman root is from Latin gutta 'drop', and the Medieval Latin form in no. 3 is a compound of another Latin word for a drop, stilla, plus cadere 'to fall', giving a meaning of 'catcher of drops' for both. OED gutter, $n .1$ notes that in the fourteenth and fifteenth centuries, gutter was "often used to render Latin stillicidium". In no. 3 there is no attempt to anglify stillicidi-, which retains Latin case-endings $-o,-i$ and the abbreviation sign for the genitive plural, $O^{6}$ orum'. DMLBS glosses stellicidium as 'gutter, spout', with attestations from 1289. Salzman (1952 [1997]: 267) however translates stillicidia as 'spouts' alone, noting that Middle English <spowt $>$ could also mean a rainwater pipe, but the Anglo-Norman Dictionary conflates the two, defining goter as 'gutter, spouting (of roof)'. (Note also both French and Latin thome le plomer and thom ${ }^{a}$ plubator in no. 3.) Stillicid- and gutter are used frequently in the St Paul's Cathedral accounts at the same dates, rigoil only occurs after 1400: DMLBS rigolus 'channel' (1292), OED rigol 'gutter' (1658), and is of uncertain origin, possibly from Middle Dutch (OED rigol, $n$.). Different clerks chose to use different lexemes for this commodity, and prior to 1390 they usually integrated them into the Latin matrix by adding a suffix (or abbreviation symbol representing a suffix) as in no. 2 .

No. 5, from early in the fourteenth century, shows integration into the Latin matrix of the compound created from [OE crowd + OE wain]. This English compound has been treated as a Latin noun, and as it is governed by the preceding preposition in (itself a visual diamorph) it has been given a suffix, represented by -ar. The addition of a suffix, whether fully spelt out or written as an emblem, could integrate pretty much any English word into the Latin matrix (names excepted):

\section{Itm die Mart in iiijor crudewanar xvjd}

(1319, Dean \& Chapter of St Paul's Cathedral, London, Rental \& Accounts, London Metropolitan Archives, CLC/313/L/D/001/MS25125/001)

'And Tuesday in 4 crowdwains (a type of handcart), 16d'

Latin suffixes on non-Latin compounds such as this mostly predate the fifteenth century. In the St Paul's Cathedral accounts a preponderance of bare forms, or

\footnotetext{
${ }^{5}$ Salzman (1952 [1992]: 266) "it is not worth while multiplying unilluminating reference to gutters."
} 
bare forms premodified by an article le/la, les, began in 1390 (in the accounts of London Bridge they are found from 1420 - the date of this innovation varies from archive to archive). ${ }^{6}$

Codeswitched elements frequently occur as simplex/compound variants. The usual practice was to write the simplex form in Latin and the compound in English or Anglo-Norman:

6) It ad supponend vnu postem \& vnu seme in la stabill \& P ij stapp P gadibz vsus Garderobam \& vno stairschide xiiijd

1396, Dean \& Chapter of St Paul's Cathedral, London, Rental \& Accounts, London Metropolitan Archives, CLC/313/L/D/001/MS25125/033

'And in propping up one post and one seam in the stable \& for 2 steps for stairs towards the garderobe and one stair-shide ('stair-board'), 14d'

7) \& in j resounpece de querc expend in alia Cama sup vnu stabulum ibm Et in $\mathrm{j}$ pec de querc ad ligand duas camas insiml ibm

1400, Dean \& Chapter of St Paul's Cathedral, London, Rental \& Accounts, London Metropolitan Archives, CLC/313/L/D/001/MS25125/040

'and in 1 reason-piece of oak used in another room over a stable there, and in 1 piece of oak for binding two rooms together there'

In no. 7 the form $<$ pec $>$ is a visual diamorph, whereas $<$-pece $>$ is written out in full, rendering it English or French but not Latin. Such compounds are usually made up of Middle English and Anglo-Norman [noun + noun] or [adjective + noun].

Turning again to no. 2, several words in this extract are visual diamorphs. They cannot be assigned specifically to Medieval Latin, Anglo-Norman French or Middle English, as they simultaneously belonged to two or more of those languages' writing systems:

$\begin{array}{ll}\text { Itm } & \text { ML, AN, ME } \\ \text { in } & \text { ML, ME } \\ \text { bord } & \text { ML, AN, ME } \\ \text { gutter } & \text { ML, AN, ME }\end{array}$

${ }^{6}$ See Wright (2010). [le + bare form] had been in use from the Norman Conquest for personal names, occupational names, place-names and locative descriptors such as le holt (see Ingham 2013); the innovation at the end of the fourteenth century was to extend the practice to a wider range of nouns. 


$\begin{array}{ll}\& & \text { ML, AN, ME } \\ \text { stipend } & \text { ML, AN, ME } \\ \text { carpent } & \text { ML, AN, ME } \\ \text { wag } & \text { ML, AN, ME }\end{array}$

Had the suffixes been written out in full, they would have belonged categorically to one or other language system, but being abbreviated, they are visually sufficient in more than one language. De Schepper and Stam (forthcoming) have extended the notion of visual diamorph to include the common ideographs used in all three languages (for example, the ampersand sign, the sign for an ounce, roman numerals) as well as abbreviation and suspension symbols. They collectively term abbreviation, suspension and other such symbols "emblems". ${ }^{7}$ Emblems, then, work as a multilingual visual shorthand, facilitating overlap of languages and blurring the distinctions between them. The form lathand in no. 8 is also a visual diamorph, as at this date (1341), the English suffix -ing had not yet entirely replaced the older English verbal noun suffix, variously spelt $<-$ and(e, -ind(e, -end(e>. These three spellings for the verbal noun suffix with $<-a-,-i-$ and -e-> letter-graphs are usually held to have had a dialectal distribution, but all three spellings are found in London mixed-language texts, corresponding to -ar-, -ir- and -er- Latin verb declensions. ${ }^{8}$

8) Itm 9putat solutu Walto Pente P parietibz lathand ex conuecioe vjs viijd

1341, Dean \& Chapter of St Paul's Cathedral, London, Rental \& Accounts, London Metropolitan Archives, CLC/313/L/D/001/MS25125/008

'And account paid to Walther Pente for lathing walls according to his contract, 6s $8 \mathrm{~d}$ '

In no. 8 the verbal noun lathand is composed of Old English lat 'lath' (also found in Anglo-Norman, see AND lath), plus the Medieval Latin gerund suffix for -arverbs, with a suspended final Latin accusative-case suffix governed by the preposition $\mathrm{ad}$. It is thus [root] + [gerund] + [suspended accusative case-ending], and it is [OE + ML]. However it is also simultaneously Old English lat, plus the Middle English verbal noun ending -and(e, so it is also [root] + [verbal noun suffix], [OE + OE]. In the 1390s (in this archive), the morpheme-ing came to be used in the verbal noun slot as well as -and, -end, -iend:

${ }^{7}$ See de Schepper and Stam (forthcoming) for an account of visual diamorphs in Medieval Latin/Medieval Irish manuscripts.

8 See Wright $(1995,2002)$ for more on the overlap between the Middle English and Medieval Latin -and-, -end- visual diamorphs. 
9) Et in DC \& dj fourpenynayll expendit similit in florying punchounyngs in gotes \& in duabz latrinis ibm ijs ijd

(1400, Dean \& Chapter of St Paul's Cathedral, London, Rental \& Accounts, London Metropolitan Archives, CLC/313/L/D/001/MS25125/040)

'And in 650 fourpenny nails used similarly in flooring puncheonings in gutters and in two latrines there, $2 \mathrm{~s} 2 \mathrm{~d}^{\prime 9}$

The -ing suffix was affixed firstly to nouns: the St Paul's Cathedral accounts contain spikyng (first attested in these accounts in 1319), sappling (1396), spyklyng (1396), punchounyng (1400); then to premodifiers in the Noun Phrase: countyngchambr (1398), hangingloks (1404), spikyngnaill (1404); and to verbal nouns governed by a preposition: P pynnyng (1391), in floryng (1393), in casting (1402). -ing was affixed to French words as well as English ones.

Emblems were a crucial part of the make-up of the text, creating visual diamorphs, and latinising non-Latin vocabulary. They were not used simply to save space. I mentioned that in the 1390s (in this archive, but at different dates in different archives), a change took place whereby non-Latin nouns that would previously have been integrated by means of an emblem, or by means of an explicit Latin case-ending, were instead expressed as a bare form or [le + noun]:

It $P$ xj saccs calcs empts $x x i j d$

(1319-20, Dean \& Chapter of St Paul's Cathedral, London, Rental \& Accounts, London Metropolitan Archives, CLC/313/L/D/001/MS25125/1)

'And for 11 sacks of chalk bought, 22d'

11) Et in xix saks calc empt de eodm Petro P opibz pdcis \& in eisdem expen pc le saks jd qa

(1393, Dean \& Chapter of St Paul's Cathedral, London, Rental \& Accounts, London Metropolitan Archives, CLC/313/L/D/001/MS25125/30

'And in 19 sacks of chalk bought from the same Peter for the aforesaid work and used in the same, price the sack, 1d farthing'

(In no. $11 \mathrm{I}$ have indicated the fine pen-stroke on the $<\mathrm{k}>$ graph, an otiose word-final flourish, not expressing plurality as it usually does elsewhere.) The formula 'precium/price le X' was particularly productive. As well as pc le saks, the St Paul's Accounts show: $1393 p c$ le $C^{n e}$ (hundred), $p c$ le $M^{l}$ ne (thousand); $1394 p c$ le bz (bushel), pc le nayl, pc le lood (load), pc le li (£); 1397 pc le taiS 'teise, a weight', pc le lb; 1398 pc le bord (board), pc le pec (piece), pc le schide (shide, a piece of

${ }^{9}$ See Wright (2012: 104-5) for further discussion of lathand, florying and punchounyngs. 
wood), pc le saplog (sap-log), pc le staff; 1400 pc le rafter; 1401 pc le poste; 1402 pc le puncheon, $p c$ le quart; 1402 pc le shell, pc le peire (pair); 1403 pc le pipe; 1405 pc le bote (boat). Indeed this may be the way in which the construction [le + noun] expanded out to other nouns from the confines of names, occupations and place-names.

Latin de +albare ('to make white', 'to whitewash', leading to 'to smooth over') became dauber in Anglo-Norman French and then English:

\section{2) Itm dealbator xviijd}

(1319-20, Dean \& Chapter of St Paul's Cathedral, London, Rental \& Accounts, London Metropolitan Archives, CLC/313/L/D/001/MS25125/1)

'And to the dauber, 18d'

13) In j daubar cugarc 9ducts $p$ x dies ad fac eosde defect ixs

1356, Dean \& Chapter of St Paul's Cathedral, London, Rental \& Accounts, London Metropolitan Archives, CLC/313/L/D/001/MS25125/14

'In 1 dauber with one mate guiding for 10 days in making (repairing) the same delapidated (building), 9s'

14) In iiij ${ }^{C}$ htlathis empt ta pro teglatore $q^{a} m$ P le dawbe ijs iijd

1391, Dean \& Chapter of St Paul's Cathedral, London, Rental \& Accounts, London Metropolitan Archives, CLC/313/L/D/001/MS25125/28

'In 400 hearthlaths bought both for the tiler and for the dauber, $2 \mathrm{~s} 3 \mathrm{~d}$ '

Dealbator in no. 12 from early in the century can only be read as Latin, midcentury daubar in no. 13 can be read as both French and English but is integrated into the Latin text by means of a word-final abbreviation symbol, whereas dawbe in no. 14, from the end of the century, is not so integrated and is expressed in the 'modern' manner of [le + bare form], without a Latin caseending or emblem representing a Latin case-ending.

Surveying the accounts as a whole, words sat on a cline of Latinity to Frenchness to Englishness according to how they were spelled. Figure 1 shows some examples:

$\begin{array}{llll}\text { Latin } & \text { Emblems } & \text { Anglo-Norman } & \text { English } \\ \leftarrow------------------------------------------------------------------\end{array}$




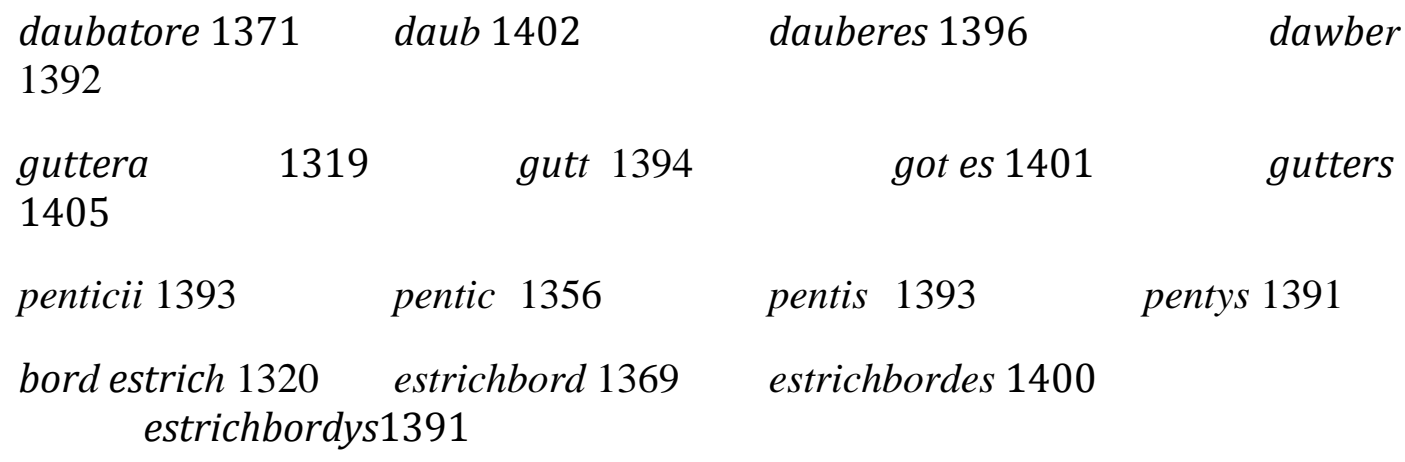

Figure 1. Cline of Latinity > Frenchness > to Englishness, with spellings and dates of first attestations in the St Paul's Cathedral Accounts, 1315-1405

In Figure 1, the Latin column shows nouns fitted into the Latin matrix by means of word-final suffixes or emblems representing such suffixes, the Emblems column is trilingual, and the Middle English and Anglo-Norman columns are interchangeable. ${ }^{10}$ The English spellings mostly post-date 1390 . I divided all the non-Latin vocabulary in these accounts (273 word-types) into words which were latinised (143, or 52\%), and words which remained unintegrated $(130$, or $48 \%)$. Integration into the Latin matrix was achieved by virtue of:

- borrowing, such as bordis 'boards', cordis 'cords', where Germanic bord was borrowed into Romance, and Greek > Latin chord was borrowed into English

- Latin word-final suffixes, such as garderobam 'garderobe, toilet', baga 'bag', where Anglo-Norman garde-robe and ?Old Norse bag were given Latin case-endings

- multilingual suffixes, such as on stallis 'stalls' (Old English steall), hespis 'hasps' (Old English hopse), which have been given a plural suffix that fits both languages orthographically

- word-final emblems, such as on gabelwall 'gable-wall', dorlach 'doorlatches', where the emblem on the word-final letter-graph enables interpretation as a Latin plural morpheme ${ }^{11}$

10 There are no uniquely-French plurals in this archive, although other accounts contain them, eg. ML kidelli, kidellorum / AN kidelx, kideux / cf ME kyddel 'type of fish-trap' (Wright 1996: 67).

${ }^{11}$ I excluded place-names (tymberheth), building-names (le catfydele), personal names (johi smalsho) and personal titles (priorisse) from the count. What to count as a word is not entirely straightforward: Kretzschmar points out that dictionaries under-represent the number of words in a language because they mainly list simplex forms as headwords, whereas speakers agglomerate simplex forms into 
Integrated vocabulary belonged simultaneously to both Latin and Anglo-Norman (portag 'portag/e, -io', from AN porter 'to carry'), or to both Latin and Middle English (scalis 'scales', from ON skál 'scale, bowl', where the Old Norse word had been borrowed into English). I treated the most frequent noun plural suffix, $-i s$, as simultaneously English and Latin, but noun plural suffix -es as simultaneously Anglo-Norman and English but not Latin, thus remaining unintegrated into the Latin matrix. I treated plural word-final emblem -s as trilingually Medieval Latin, Anglo-Norman and Middle English; but plural suffix -ys as unintegrated, as it is not part of the Latin orthographical system. Emblems were crucial: Old Englishderived words such as flor 'floor', stall 'stall', spikyng 'spiking', are integrated visual diamorphs only by virtue of their word-final emblems, without which they would remain unintegrated and monolingual. Almost half the Anglo-Norman and Middle English vocabulary was not integrated, either because it was not given any kind of Latin word-final suffix, or abbreviation representing a Latin suffix (chymeney 'chimney', cole 'glue'), or because it was spelt with letter-graph sequences which were not part of the Latin orthographic system (swelewe 'swallow, drain', stulpys 'bollards').

How was the non-Latin appearance of the non-integrated words at $48 \%$ expressed on the membrane? In particular, $\langle\mathrm{y}, \mathrm{k}, \mathrm{w}\rangle$ graphs did not belong to the Latin spelling system, nor did certain digraphs and trigraphs:

- the $<\mathrm{k}>$ graph was used in this archive (proper nouns included): plaunk 'plank' (1341), clikets 'clicket' (1340), Berkyngchirch (name, 1383), boket 'bucket' (1389), le wyket 'wicket', le saks (1393), pekks 'peck' (1395), kokyr '?cocker' (1395), coker '?cocker' (1397), bloks 'blocks' (1397), hoks 'hooks', (1397), rakkys 'rakes' (1398), Kyng (name, 1398), Haydok (name, 1400), Brakele (name, 1400), Bokeleresbury (name, 1400), Bokeland (name, 1400), okenbord 'oakenboard' (1400), Stockes (name, 1402), stoklokkes (1404), Baker (name, 1404), Kyngkyston (name, 1405), Le Pekoks (name, 1405), Garlekheth (name, 1405)

more complex structures (compounds, compounds plus morphemes, phrases): “The number of entries for headwords in the dictionary, for example, grossly underestimates the possible units in the lexicon if we take multi-word collocations into account" (Kretzschmar in press: 30). I have been more conservative than Kretzschmar, who includes e.g. 'one little dry spell' as an example of a multi-word unit, but I have included words such as longbechelath, 'long beech-lath', brodeheuedenaill 'broad-headed nail', shorthertlathis 'short heart-laths', vpperiztroffs 'upright-trough', as their formation is regular: monolingual Latin second-elements are rare, if they occur at all: Paulysnayl 'Paul's-nail' not *Paulysclavis; hangingloks 'hanging-lock' not *hangingcerur. The Dictionary of Medieval Latin from British Sources often contains such words considerably earlier than those listed by the Oxford English Dictionary and the Middle English Dictionary, and Trotter (2014b: 169) observes that dictionaries have trouble with words first found in another language: "In common with the $M E D$ and $O E D$, and increasingly as time went on successive fascicles of the $D M L B S$, the AND does not reject words merely because they are attested in the "wrong" language". 
- the St Paul's Cathedral accounts-clerks rarely if ever used a $<y>$ graph in words belonging to Medieval Latin: clavis 'nails', teglis 'tiles', pinnis 'pins', saccis 'sacks', ibidm 'there'; never *tegulys, *dyes (dies, 'days'), *unyus (unius, 'one'). Anglo-Norman and Middle English words, on the other hand, took both $<\mathrm{i}>$ and $<\mathrm{y}>$, names included: spyklyng 'spikling' (ME, 1396), Thamesyam (name, 1398), Thamysia (name, 1398), latys 'lattice' (AN, 1400), Turrym london (name, 1405)

- post-vocalic backglides/length-markers are variably realized as $<$ w $>$ in non-Latin words only: Pouleswharf (name, 1369), Powleswharfs (1395); dawber (1395), dauber (1396); Brownyng (name, 1397), Brounynge (1405); sowder (AN, 1395)

- certain digraphs were restricted to words of English etymology: <wh->: wharfag (1319), whyzte (name, 1405); <wr->: Wrenne (name, 1404). The sh digraph/trigraph occurs in words of English and French etymology with five variants sh, sch, ssch, chs, ssh: schop (1315), masschrother (1341), flaundrchstiles (1397), flaundrisshtyll (1400), shop (1402)

Orthographic practice was as crucial for the non-Latin-looking words as emblems were for the integrated words. The mechanisms of codeswitching, glossing, compounding, emblem-usage and orthographical convention served to create an integrated multilingual text, but also to keep Middle English and Anglo-Norman on the one hand distinct from Medieval Latin on the other. ${ }^{12}$

It has been mentioned that there was a change around 1390 (the introduction of [le + bare form] and consequent loss of Latin case-agreement; the introduction of deverbal -ing forms; plurals in $-y s$ rather than -is), which change had been building up in the preceding decades. For example, the early fourteenth century words for the parts of a door-hinge in the St Paul's Cathedral accounts were gumphis vtiuellis hespis \& stapul. By the financial year 1369-70, Anglo-Norman gumphis and vtiuellis had changed to English hokys \& hengs. However this apparent replacement cannot represent a wholesale shift in speech, because $O E D$ has attestations of vertiwell (spread out under headwords vartiwell, $n$. and vardle, $n$., ultimately derived from

12 This observation has already been made by Trotter (2010: 60), who observed that the articles le/la/les in mixed-language texts preceded only non-Latin words, not Latin words. He concluded that there was a binary system in operation, Medieval Latin on the one hand versus Anglo-Norman/Middle English on the other, rather than a ternary one. Ingham (in press) on the other hand sees le/la/les as a short codeswitched string. Either way, it does not imply that scribes did not know their English from their French (see Ingham (2011: 100), Wright (2013: 20-23)). It is probably this keeping of English and Anglo-Norman orthographically distinct from Medieval Latin that led Howlett (1997:89) to claim that "when Anglo-Saxons wrote English they wrote English, and when they wrote Latin they wrote Latin. They did not contaminate their Latin with English", although they did in fact codeswitch: this comment was quoted by Schendl (2011: 47) in a paper demonstrating Old English/Latin codeswitching. 
Latin vertibulum 'joint') still in use in late nineteenth century East Anglian English. ${ }^{13}$ The East Anglian quotations (copied from $E D D$ ) are from a Lincolnshire dialect word-list: "vartiwells, a part of a hinge to a gate" (1866), "vartiwell, the eye of a gate in which the crook works" (1877), and a description of Norfolk dialect: "vardle, a common eye or thimble of a gate, with a spike only" (1787), "vardle, bottom hinge of a gate" (1893). The route of entry into English went from Latin vertibulum > Anglo-Norman vertivel (AND: "vertivel, a hengle Westm Glosses") > Middle English vertiwell > Modern English vardle. In order for phoneticallydistinct variants to have evolved in East Anglia, the vertiwell-derived words must have continued to be used, presumably spoken by the kind of workmen who worked with hinges, and passed on to his mate (garcio, serviente, famulo).

Of the 130 unintegrated non-Latin words, 35 pre-date 1390, and 95 post-date 1390. There is more text extant from later years as later rolls are longer and fuller than earlier ones, but even so, the addition of increased ratios of English to Latin chimes with developments in other contemporaneous accounts. ${ }^{14}$ The admission of more and more Middle English into the Latin matrix must have had an effect on register. If Medieval Latin was a vehicle for a formal, high style, then admixing greater amounts of the two vernaculars into Medieval Latin must have adjusted that style. Textbooks teach that the register of Anglo-Norman was courtly, legal and generally high in contradistinction to Middle English, but the increasing presence of Anglo-Norman and Middle English in Medieval Latin writing conveyed a register-shift, akin to a move from First Class to Business Class. The mixed-language system was deemed appropriate for stewardship, be it of grand perpetual institutions like St Paul's Cathedral and London Bridge, of private individuals such as the London businessman Gilbert Maghfeld, or the numerous religious foundations, manors, estates and farms around the country that gave rise to the Anglo-Norman field names and country vocabulary identified by Trotter (2014a, and see also Rothwell 2008, 2009, 2012). It is surely safe to say that a country term for the bottom hinge of an East Anglian gate was not the kind of thing that textbook authors had in mind when they claimed that Anglo-Norman was high-register, but the implicit contradiction exists only if monolingual, monoregister Anglo-Norman is the only system taken into account. The mixed-language system connoted a register of trade and commerce, of land and money management, of asset movement and inventory. The vernacular element, which the clerks presented as such by not integrating it into the matrix language, had the effect of distinguishing this register from all other (monolingual) registers.

Nonetheless, it is by no means certain that this was any kind of conscious ploy. Ingham $(2010,2011,2012,2013)$ has pinpointed the end of the fourteenth century as the time when Anglo-Norman ceased to be passed on to young children in the classroom, as British Anglo-Norman written after that date shows the kinds of errors

13 OED has no quotations prior to 1525 ("For hengells, verdolls, \& hoks, hespes \& staples") as for this headword, mixed-language texts were not surveyed. See also $E D D$ vartiwell, sb. and vardle, sb.

${ }^{14}$ See Wright (in press) for a discussion of other late-fourteenth, early fifteenthcentury changes, including a period of codeswitching as a sustained norm between 1420 and 1440 in the Mercers' Company archive, as identified by Alcolado Carnicero (2013). 
made by second-language learners in adulthood. The cumulative changes mentioned here, including the $48 \%$ non-integrated codeswitches, may be due to that adult learning experience. Whether or no, they became the professional norm for clerks in the fifteenth century, up until the 'tip' point was reached (at different times in different archives) and the wholesale shift to monolingual English resulted in the abandonment of the mixed-language system.

\section{Appendix}

Unintegrated Anglo-Norman and Middle English vocabulary in the Dean and Chapter of St Paul's Cathedral Rental \& Accounts, 1315-1405. N = 130

\begin{tabular}{|c|c|c|}
\hline Year & $\begin{array}{l}\text { Middle English word } \\
\text { (context only if explanatory) }\end{array}$ & Remarks \\
\hline $\begin{array}{l}1315-16 \\
1391\end{array}$ & $\begin{array}{l}\text { tylpynnes 'tile-pin' } \\
\text { tylepynnys }\end{array}$ & $\begin{array}{l}M E D \text { tile (n.(2))2.b. } 1333 \\
O E D \text { tile-pin, } n . \mathrm{OE}+\mathrm{OE} \\
1338\end{array}$ \\
\hline $1319-20$ & $\begin{array}{l}\text { squadders 'some type of } \\
\text { workman': In ij squadders } \\
\text { cu j suient p duos dies xviijd }\end{array}$ & ?AN \\
\hline $1319-20$ & lednail 'lead-nail' & $\begin{array}{l}M E D \text { led (n.)2b.(b) 1303; } \\
D M L B S \text { lednaila } 1337 ; O E D \\
\text { lead, } n .1 . C 3 . \text { OE + OE lead- } \\
\text { nail } 1355\end{array}$ \\
\hline $\begin{array}{l}\text { 1319-20 } \\
\text { undated membrane, } \\
\text { c1320 }\end{array}$ & $\begin{array}{l}\text { lattenail 'lath-nail' } \\
\text { lathenayl }\end{array}$ & $\begin{array}{l}\text { MED lat (n.)c. 1272-3; } \\
D M L B S \text { lathnailum 1346; } \\
\text { OED lath-nail, n. } 0 E+O E \\
1388-9\end{array}$ \\
\hline 1319-20 & railles 'rails' & $\begin{array}{l}D M L B S \text { railla c1155; OED } \\
\text { rail, } n .^{2} \text { AN } 1313-14 ; T L \text { rail } \\
\text { c1320; } A N D \text { raille }\end{array}$ \\
\hline 1319-20 & $\begin{array}{l}\text { cole 'paste, glue': In iij } \\
\text { saccis vini calci cu cole ad } \\
\text { dealband dom vd }\end{array}$ & $\begin{array}{l}D M L B S \text { colla } 9 \ldots ; T L \text { colle, } \\
\text { subst. fém. } 1268 ; M E D \text { cole } \\
\text { (n.) (a) 'glue or size' } 1296 \text {; } \\
A N D \text { cole }^{1} 1399 ; \text { not in } \\
O E D\end{array}$ \\
\hline $1319-20$ & $\begin{array}{l}\text { teyses 'teises, linear } \\
\text { measure': Itm soluto } \\
\text { pauator pro xxxiiijor Teyses } \\
\text { pauant vijs jd pc Teys ijd ob }\end{array}$ & $\begin{array}{l}D M L B S \text { teisa } 1198 ; M E D \\
\text { teis (n.) } 1296-7 ; O E D \text { teise } \\
\text { taise, } n .2 . \text { 'a superficial } \\
\text { measure' AN } 1426-7\end{array}$ \\
\hline $1319-20$ & $\begin{array}{l}\text { rebouse 'rubbish': Itm } \\
\text { soluto iiijor croudewanar die } \\
\text { lune car rebouse circa dcm } \\
\text { pauiment xvjd quilz p die } \\
\text { iiijd }\end{array}$ & $\begin{array}{l}D M L B S \text { robousa } 1259 ; O E D \\
\text { rubbish, } n ., \text { adj., and int. } \\
\text { ?AN } c 1400 ; A N D \text { robouse }\end{array}$ \\
\hline $1319-20$ & loupeledes 'loopleads, & ?Celtic + OE \\
\hline
\end{tabular}




\begin{tabular}{|c|c|c|}
\hline & $\begin{array}{l}\text { window-leads': In iiij libr } \\
\text { plubi P loupeledes xiijd }\end{array}$ & \\
\hline 1336 & $\begin{array}{l}\text { torchr 'dauber': In stipend } \\
\text { vni torchr } p \text { tres dies xvjd }\end{array}$ & $\begin{array}{l}D M L B S \text { torchator 'one who } \\
\text { daubs or plasters' } 1287 ; \\
O E D \text { torcher, n.2 'a } \\
\text { workman employed in } \\
\text { torching' AN } 1851 \text {; cf } A N D \\
\text { torche 'clay, daub'; cf } O E D \\
\text { torch, } v .2 \text { 'to point the } \\
\text { inside joints of slating laid } \\
\text { on lath with lime hair } \\
\text { mortar', from AN torche } \\
\text { 'twisted straw' }\end{array}$ \\
\hline 1340 & $\begin{array}{l}\text { masschrothers 'mash- } \\
\text { rudders, paddles for } \\
\text { stirring mash': Itm in ij } \\
\text { masschrothers empts iiijd }\end{array}$ & $\begin{array}{l}\text { MED mash-rother (n.) } \\
1446 ; \text { OED mash, } n .1 \mathrm{C} .2 \\
\text { mash-rudder } 1454 ; \\
\text { rudder, } n . I I .5 . \text { 'paddle or } \\
\text { pole used to stir the malt } \\
\text { in a mash tun' OE + OE } \\
1410\end{array}$ \\
\hline 1340 & cleys 'clayes, hurdles' & $\begin{array}{l}T L \text { claie subst. fém. 'treillis } \\
\text { d'osier à claire-voie tendu } \\
\text { sur un support en } \\
\text { bois'1155; } D M L B S \text { cleta } \\
1291 \text { 'hurdle for } \\
\text { scaffolding'; OED claye, } n \text {. } \\
\text { 'hurdle' c1307 AN; AND } \\
\text { cleie }\end{array}$ \\
\hline 1341 & schop 'shop' & $\begin{array}{l}\text { OED shop, } n \text {. OE; DMLBS } \\
\text { shop/a } 1189 ; M E D \text { shop(pe } \\
\text { (n.); } A N D \text { shope }\end{array}$ \\
\hline 1341 & $\begin{array}{l}\text { torale 'furnace, kiln': In vno } \\
\text { cilicio empts } P \text { torals ijs vjd } \\
\text { In duabz cleys empts } P \\
\text { torale xvd }\end{array}$ & $\begin{array}{l}D M L B S \text { toral/e 'kiln' a1183; } \\
T L \text { touraille 'Étuve où } \\
\text { s'effectue le chauffage du } \\
\text { malt pour en arrêter la } \\
\text { germination' 13thc; } A N D \\
\text { toraille 'kiln' }\end{array}$ \\
\hline 1341 & $\begin{array}{l}\text { tundur 'funnel': In vno } \\
\text { tundur empts iiijd }\end{array}$ & $\begin{array}{l}M E D \text { tonour (n.) } 1337 \\
O E D \text { tunder, } n . \text { AN } 1343-4 \\
A N D \text { tunor }\end{array}$ \\
\hline 1341 & $\begin{array}{l}\text { alehop 'ale-hoop, container } \\
\text { for ale': Itm j alehop \& vna } \\
\text { ptica empts vjd }\end{array}$ & $\mathrm{OE}+\mathrm{OE}$ \\
\hline 1341 & plomer 'plumber' & $\begin{array}{l}T L \text { plombier } 1266 ; O E D \\
\text { plumber, } n . \text { AN } 1385-6 ; \\
M E D \text { plumber (n.) } 1399- \\
1400 ; D M L B S \text { plumbarius } \\
1428\end{array}$ \\
\hline 1349 & stayre 'stair' & OED stair, $n$. OE; DMLBS \\
\hline
\end{tabular}




\begin{tabular}{|c|c|c|}
\hline & & steira 1282 \\
\hline $\begin{array}{l}1349 \\
1405\end{array}$ & $\begin{array}{l}\text { ryngges 'rings' } \\
\text { ryngys }\end{array}$ & $\begin{array}{l}\text { OED ring, } n .^{1} \text { OE; } D M L B S \\
\text { ringa } 21284\end{array}$ \\
\hline 1349 & $\begin{array}{l}\text { lacche 'latch': Ite P j lacche } \\
\text { \& ij stapul apud } \\
\text { Sarmoneslane jd ob; } \\
\text { lacchys }\end{array}$ & $\begin{array}{l}\text { MED lacch(e (n.) 1296-7; } \\
D M L B S \text { lacchea 1297; OED } \\
\text { latch, } n^{l} \text { AN ?a1366; AND } \\
\text { lacche }^{1}\end{array}$ \\
\hline 1349 & $\begin{array}{l}\text { qartron 'quartron': In } p^{i} \text { mis } \\
\text { in j qartron de Estrichbord } \\
\text { empts iijs vijd ob }\end{array}$ & $\begin{array}{l}D M L B S \text { quartero a1224 } \\
\text { 'quartron, quarter of a } \\
\text { hundredweight'; OED } \\
\text { quartern, } n .^{2} 3 . \text { a. 'quarter of } \\
\text { a hundredweight' AN } 1423 \text {; } \\
M E D \text { quartroun (n.) } 1 .(\mathrm{c}) \\
1423\end{array}$ \\
\hline 1349 & pounchouns 'puncheons' & $\begin{array}{l}\text { DMLBS puncho } 1236 \\
\text { 'strut'; OED puncheon } n .{ }^{l} \\
\text { II.4 'upright piece of } \\
\text { timber' AN 1348; AND } \\
\text { ponchon }\end{array}$ \\
\hline 1349 & holltiles 'hollow-tile' & $\begin{array}{l}\text { MED tile (n.(2))2.(b) } \\
\text { hole } 1363-4 ; O E D \text { hollow, } \\
\text { adj. and } a d v . \text { S1.a. } \\
\text { hollowtile OE + OE } 1914\end{array}$ \\
\hline 1349 & $\begin{array}{l}\text { dressyngbordes 'dressing- } \\
\text { boards': Itm in ij Dressyng } \\
\text { bordes empts xviijs }\end{array}$ & $\begin{array}{l}\text { DMLBS dressor a. .. bordes } \\
\text { 1307; OED dressing-board, } \\
\text { n. 'board on which food was } \\
\text { dressed, dresser' AN + OE } \\
c 1440 ; \text { MED dressinge (ger. } \\
\text { 2.(a) bord } 1380\end{array}$ \\
\hline 1349 & roufnayl 'roof-nail' & $\begin{array}{l}\text { OED roof, } n \text {. C3. roof-nail } \\
\text { OE }+ \text { OE } 1284\end{array}$ \\
\hline 1349 & $\begin{array}{l}\text { estrichbord: 'est-rich- } \\
\text { board, 'board from the } \\
\text { eastern kingdom': In p } p^{i} \text { mis } \\
\text { in j qartron de Estrichbord } \\
\text { empts iijs vijd ob; } \\
\text { estrichbordys }\end{array}$ & $\begin{array}{l}D M L B S \text { estrichborda } 1335 ; \\
M E D \text { est-rich-bord (n.) OE } \\
+ \text { OE + OE 'timber from } \\
\text { Baltic or Norway' } 1334-5 ; \\
O E D \text { estriche, } n .2 \text { estrich } \\
\text { board } 1350\end{array}$ \\
\hline 1356 & $\begin{array}{l}\text { gapiars 'type of window': It } \\
\text { in plubo epts } P \text { loupes \& } \\
\text { gapiars xvd }\end{array}$ & $\begin{array}{l}\text { ?gape 'open wide' + AN } \\
\text { suffix; Salzman (1952 } \\
\text { [1997]: } 511 \text { fn 5): gapiers } \\
\text { 'dormer windows' } \\
\end{array}$ \\
\hline 1356 & oker 'ochre' & $\begin{array}{l}\text { DMLBS ochra CL; MED } \\
\text { oker (n.(2)) 1296; TL ochre } \\
\text { 1307-09; OED ochre | } \\
\text { ocher, } n \text {. and adj. AN } 1364\end{array}$ \\
\hline $1369-70$ & hokys 'hooks' & $\begin{array}{l}\text { OED hook, n. } \text { ' OE; DMLBS } \\
\text { hokum } 11342\end{array}$ \\
\hline $1369-70$ & $\begin{array}{l}\text { latthen 'lath-nails': In } i j^{C} \\
\text { latthen xvjd }\end{array}$ & $\begin{array}{l}\text { Cf } O E D \text { lathen, adj. 'made } \\
\text { of lath' } 1843\end{array}$ \\
\hline
\end{tabular}




\begin{tabular}{|c|c|c|}
\hline $1369-70$ & $\begin{array}{l}\text { traunson 'transom-nails': In } \\
M^{l} \text { traunson xijd }\end{array}$ & $\begin{array}{l}O E D \text { transom, } n .5 \text {. 'short } \\
\text { for transom-nail, } n \text {.' ?L } \\
1423 ; M E D \text { traunsom (n.) } \\
\text { (a) 'nails for beams' } 1423\end{array}$ \\
\hline $1369-70$ & chymeney 'chimney' & $\begin{array}{l}\text { TL cheminée c1170; } \\
D M L B S \text { cheminea } 1201 ; \\
\text { OED chimney, } n . \text { AN } \\
a 1330 ; A N D \text { chiminee }\end{array}$ \\
\hline $\begin{array}{l}1371 \\
1391\end{array}$ & $\begin{array}{l}\text { plate 'plate': It in v pec } \\
\text { maeremij \& j plate xvjd } \\
\text { platys 'plates' }\end{array}$ & $\begin{array}{l}D M L B S \text { platus } 10 \text { 'flat piece } \\
\text { of wood' } 1279 ; \text { OED plate, } \\
n \text {. II.12 'horizontal beam of } \\
\text { timber' AN } a 1395\end{array}$ \\
\hline 1371 & hengys 'hinges' & $\begin{array}{l}D M L B S \text { henga } 1314 ; M E D \\
\text { henge (n.) 1356; OED } \\
\text { hinge, } n . * \text { OE c1380; AND } \\
\text { henge }\end{array}$ \\
\hline 1383 & masons 'masons' & $\begin{array}{l}\text { TL maçon subst. masc. } \\
\text { 'ouvrier qui exécute des } \\
\text { travaux de maçonnerie' } \\
1155 ; D M L B S \text { macio } 1166 \text {; } \\
\text { OED mason, } n .^{l} \text { AN } c 1275 \text {, } \\
\text { composed ?a } 1200\end{array}$ \\
\hline 1391 & postys 'posts' & $\begin{array}{l}D M L B S \text { postis CL; OED } \\
\text { post, } n .{ }^{l} \mathrm{OE}\end{array}$ \\
\hline 1391 & $\begin{array}{l}\text { bem 'beam': Idem computat } \\
\text { in memio empt P emendacoe } \\
\text { vni coquine \& aliaO } \\
\text { domoO infa hospic dni } \\
\text { Thome Boteler in poch sci } \\
\text { Georgij in Estchep vidlt P ij } \\
\text { postys j bem iij platys xviij } \\
\text { qart is memij quercm vij } \\
\text { rafterys \& ij bracys pcii in } \\
\text { toto xxvijs viijd }\end{array}$ & $\begin{array}{l}\text { Cf } D M L B S \text { bemum 'plough- } \\
\text { beam'; } O E D \text { beam, } n .{ }^{l} \mathrm{OE}\end{array}$ \\
\hline 1391 & rafterys 'rafter' & $\begin{array}{l}\text { DMLBS raftera Reg.S.Aug.; } \\
\text { OED rafter, } n .{ }^{l} \text { OE }\end{array}$ \\
\hline $\begin{array}{l}1391 \\
1404\end{array}$ & $\begin{array}{l}\text { bracys 'arched roofbeam' } \\
\text { brace: It in j Brace \& j gy< } \\
>\text { vjd }\end{array}$ & $\begin{array}{l}D M L B S \text { brachium } 10 . \mathrm{d} \text { 'tie- } \\
\text { beam' } 1233 ; \\
O E D \text { brace, } n .{ }^{2} \text { IV.17.a. } \\
\text { 'timber used in a roof' AN } \\
1530 ; M E D \text { brace (n.) } 4 . \text { (c) } \\
1348 ; A N D \text { brace } 3 \text { 'arched } \\
\text { wooden beam' }\end{array}$ \\
\hline 1391 & $\begin{array}{l}\text { courbys 'curbs': In ij } \\
\text { courbys empt P vno fonte } \\
\text { ibm iijs vjd }\end{array}$ & $\begin{array}{l}\text { DMLBS curba 1228; TL } \\
\text { courbe 'pièce de bois } \\
\text { cintrée' adj. et subst. } 1314 \text {; } \\
\text { OED curb, } n \text {.III.8.a. 'frame } \\
\text { or 'coaming' round the top } \\
\text { of a well to which the lids } \\
\text { are fastened' AN 1511; }\end{array}$ \\
\hline
\end{tabular}




\begin{tabular}{|c|c|c|}
\hline & & $\begin{array}{l}M E D \text { courbe (n.) 'curved } \\
\text { piece of timber' } 1291-2\end{array}$ \\
\hline 1391 & htlathys 'heartlaths' & $\begin{array}{l}\text { DMLBS hertlatha 1333; } \\
\text { OED heart, } n ., \text { int., and } a d v . \\
\text { C3.a. heart lath OE + OE } \\
\text { 1324; MED hart-lat (n.) } \\
\text { 'lath made from } \\
\text { heartwood' } 1332\end{array}$ \\
\hline 1391 & $\begin{array}{l}\text { pentys 'pentice': In iij } \\
\text { tablis empt ixd P pentys }\end{array}$ & $\begin{array}{l}D M L B S \text { penticium } 1211 \text {; } \\
\text { OED penthouse, } n \text {. AN } \\
a 1400 c 1300 ; M E D \text { pentis } \\
\text { (n.) } 1348\end{array}$ \\
\hline 1391 & $\begin{array}{l}\text { shorys 'shores': In viij } \\
\text { shorys \& iij claiiys memij } \\
\text { conduct ad erigend \& } \\
\text { supportand dict ten xjd }\end{array}$ & $\begin{array}{l}M E D \text { shore (n.(3)) ‘prop' } \\
\text { 1294-5; DMLBS schorum } \\
\text { 'prop' 1389; OED shore, } n .^{3} \\
\text { 1.a. MDu/MLG, ON c1440 }\end{array}$ \\
\hline 1391 & leggys 'ledges' & $\begin{array}{l}D M L B S \text { legga } 1279 ; \text { OED } \\
\text { ledge, } n \text {. Gmc, ?OE } c 1330\end{array}$ \\
\hline 1391 & $\begin{array}{l}\text { dawbe 'dauber': In iiijC } \\
\text { htlathis empt ta pro } \\
\text { teglatore qa } q^{a} \text { P le dawbe } \\
\quad \text { ijs } \\
\text { iijd }\end{array}$ & $\begin{array}{l}\text { DMLBS daubator } 1274 ; \\
\text { OED dauber, } n . \text { AN } c 1300 \text {; } \\
M E D \text { dauber (n.) } 1263\end{array}$ \\
\hline 1392 & lym 'lime' & $\begin{array}{l}D M L B S \text { limus 'mud as } \\
\text { building material' CL; OED } \\
\text { lime, } n .^{l} 2 . \text { 'cement' OE }\end{array}$ \\
\hline 1392 & lathys 'laths' & $\begin{array}{l}D M L B S \text { lata } 1130 ; O E D \\
\text { lath, } n . \mathrm{OE}\end{array}$ \\
\hline 1392 & $\begin{array}{l}\text { bayl 'bail': It in vna pecia } \\
\text { maeremij P j Bayl inde } \\
\text { faciend P fenestra in Cama } \\
\text { Camarij dni Thome pcy iijd }\end{array}$ & $\begin{array}{l}\text { OED bail, } n .^{4} \text { AN cross-bar } \\
1575\end{array}$ \\
\hline 1393 & saks 'sack' & $\begin{array}{l}D M L B S \text { saccus CL; OED } \\
\text { sack, } n .^{1} \mathrm{OE}\end{array}$ \\
\hline 1393 & farecost, varecost 'boat' & $\begin{array}{l}D M L B S \text { farcosta } 1284 ; O E D \\
\text { farcost, } n \text {. ON } 1284\end{array}$ \\
\hline 1393 & $\begin{array}{l}\text { suelwe, swelewe 'swallow, } \\
\text { drain' }\end{array}$ & $\begin{array}{l}M E D \text { swolwe (n.) (g) } \\
\text { 'drain' a1450; cf } O E D \\
\text { swallow, } n^{2} \text { 'a deep hole' } \\
\text { OE }\end{array}$ \\
\hline 1393 & $\begin{array}{l}\text { stulpys 'posts, bollards': Et } \\
\text { johi kyng P Cxvj ped Bord } \\
\text { voc Plankebord ab eo empt } \\
\text { \& expend in factura cui9da } \\
\text { suelwe in hospic Thome pcy } \\
\text { cont in longit vj ped \& in } \\
\text { latitud iiij ped pc ijs ixd ob } \\
\text { Et eidm johi P ix stulpys \& } \\
\text { Jystes ab eo empt \& in opibz }\end{array}$ & $\begin{array}{l}D M L B S \text { stolpa } 1289 ; \text { OED } \\
\text { stoop, } n .{ }^{1} 1 . \text { a. ON } 1439 ; \\
M E D \text { stulp(e (n.) 'stake' } \\
1350\end{array}$ \\
\hline
\end{tabular}




\begin{tabular}{|c|c|c|}
\hline & pdcis expend $x d$ & \\
\hline 1393 & $\begin{array}{l}\text { pacys 'steps': Et in vad } \\
\text { duoO sarratoO sarrant } \\
\text { maerem P pdicts Pacys inde } \\
\text { faciend }\end{array}$ & $\begin{array}{l}\text { OED pace, } n .^{I} \text { IV.10. 'part } \\
\text { of a floor, step' AN } 1423 \text {; } \\
T L \text { pas }^{2} \text { subst. c. } 1180 \\
\text { 'marche de départ d'un } \\
\text { escalier?'; } 1340 \text { 'marche } \\
\text { d'escalier'; } A N D \text { pas }^{1} 4 \\
\text { 'step of stairway' }\end{array}$ \\
\hline 1393 & 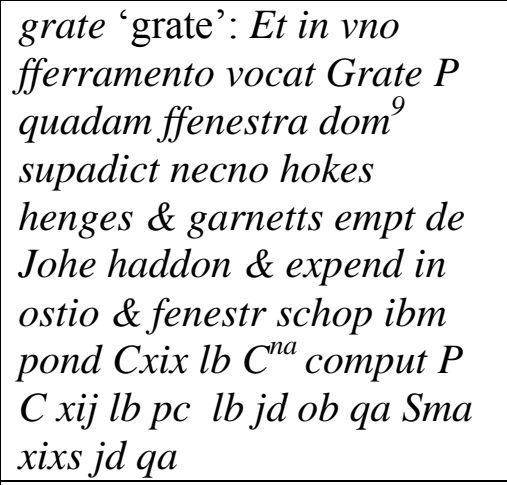 & $\begin{array}{l}D M L B S \text { grata } 1429 \\
\text { 'grating'; OED grate, } n .{ }^{l} \\
\text { 'framework of bars' AN } \\
\text { c1440; } A N D \text { grate } 2 \\
\text { 'grating' } 1408 / 9 ; M E D \text { grate } \\
\text { (n.(1)) 'grating' } 1423\end{array}$ \\
\hline 1393 & $\begin{array}{l}\text { mantel 'chimney } \\
\text { mantelpiece' }\end{array}$ & $\begin{array}{l}\text { DMLBS mantellum } 1237 \\
\text { CL 'mantle'; TL manteau } \\
\text { subst. masc. 'partie } \\
\text { supérieure de la cheminée } \\
\text { qui couvre la hotte' } 1332 ; \\
O E D \text { mantel, } n \text {. AN } 1357\end{array}$ \\
\hline 1393 & $\begin{array}{l}\text { wyket 'wicket, small door or } \\
\text { gate in or alongside larger } \\
\text { door or gate' }\end{array}$ & $\begin{array}{l}D M L B S \text { wikettum } 1198 \\
O E D \text { wicket, } n \text {. AN } 12 . .\end{array}$ \\
\hline 1393 & jystes 'joists' & $\begin{array}{l}\text { DMLBS gista } 1199 ; \text { OED } \\
\text { joist, } n .^{l} 1294\end{array}$ \\
\hline 1393 & $\begin{array}{l}\text { plankebordnayl } \\
\text { 'plankboard-nail': Et in } \\
M^{l} C C \text { clau voc } \\
\text { Plankebordnayl empt \& in } \\
\text { opibz pdcis expend pc } C^{\text {ne }} \text { vd } \\
\text { Sma vs }\end{array}$ & $\begin{array}{l}\text { Cf } O E D \text { plank board, } n . \\
1444 ; M E D \text { plank(e } \\
\text { (n.)1.(b) bord AN + OE + } \\
\text { OE } 1444\end{array}$ \\
\hline 1393 & $\begin{array}{l}\text { longelathes 'long-laths': Et } \\
\text { in } M^{l} M^{l} \text { longelathes empt de } \\
\text { Johe Aysschele P opibz apd } \\
\text { domu pdict faciend \& in } \\
\text { eisdem expendend pc } M^{l} n e \\
\text { vs Smaxs }\end{array}$ & $\mathrm{OE}+\mathrm{OE}$ \\
\hline 1394 & $\begin{array}{l}\text { schadde 'shed': It p Johem } \\
\text { Tykhill mense julij in } \\
\text { emendacone vni' schadde vz } \\
\text { P meremio empt \& ope viijd }\end{array}$ & $\begin{array}{l}\text { OED shud, } n . \text { ?MLG c1440, } \\
\text { shed, } n .{ }^{2} 1 . \text { a. } 1457 ; M E D \\
\text { shud(de (n.) } 1440 ; D M L B S \\
\text { shuddum } 1442\end{array}$ \\
\hline 1394 & $\begin{array}{l}\text { scauegours 'scavagers, } \\
\text { officers who collected a toll' }\end{array}$ & $\begin{array}{l}D M L B S \text { scawagium } 1267 ; \\
O E D \text { scavager, } n \text {. AN } 1307 ; \\
\text { AND scawageour }\end{array}$ \\
\hline 1394 & hayhous 'hayhouse': It & OED hay-house, $n$. OE \\
\hline
\end{tabular}




\begin{tabular}{|c|c|c|}
\hline & $\begin{array}{l}\text { Custus repaconis Hospicij } \\
\text { Thome Percy MenS Julij \& } \\
\text { August Magne Came Aule \& } \\
\text { la Hayhous }\end{array}$ & heghus \\
\hline 1394 & $\begin{array}{l}\text { nayl 'nail': It P iiij nayll } \\
\text { plumbi ad magnu Caminu } \\
\text { ibm pc le nayl vjd }\end{array}$ & $O E D$ nail, $n . \mathrm{OE}$ \\
\hline 1394 & traunsunayl 'transom-nail' & $\begin{array}{l}\text { OED transom, } n . \mathrm{C} 2 . \\
\text { transom-nail ?AN + OE } \\
1359 ; \text { MED traunsom (n.) } \\
\text { (a) nail } 1359\end{array}$ \\
\hline 1394 & lood 'load' & $\begin{array}{l}D M L B S \text { lada } 3 \text { 'load' } \\
\text { p1163; OED load, } n \text {. OE }\end{array}$ \\
\hline 1394 & florys 'floors' & $O E D$ floor, $n .^{l} \mathrm{OE}$ \\
\hline 1394 & $\begin{array}{l}\text { harthlome 'hearth-loam': It } \\
\text { P vna carect de harthlome } \\
\text { viijd }\end{array}$ & $\mathrm{OE}+\mathrm{OE}$ \\
\hline 1394 & $\begin{array}{l}\text { fyfpenynayl 'fivepenny- } \\
\text { nail: It } P j C \text { \& dj fyfpenynayl } \\
\text { vijd ob }\end{array}$ & $\begin{array}{l}\mathrm{OE}+\mathrm{OE}+\mathrm{OE} ; \operatorname{cf} O E D \\
\text { fivepenny, adj. }\end{array}$ \\
\hline 1394 & $\begin{array}{l}\text { paulys nayl: 'Paul's- nail': It } \\
\text { P clauis ad ide vocat Paulys } \\
\text { nayl ijd ob }\end{array}$ & $\mathrm{OE}+\mathrm{OE}$ \\
\hline $\begin{array}{r}1394 \\
1397 \\
\end{array}$ & $\begin{array}{l}\text { pewes 'pews': It } P \\
\text { meremio P pewes fenestraO } \\
\& \text { punchouns ibdm } x d ; \\
\text { pewys }\end{array}$ & $\begin{array}{l}\text { OED pew, } n . \text { OF } c 1400 \\
? a 1397 ; M E D \text { peu(e (n.(1)) } \\
c 1400 ? a 1397 ; D M L B S \\
\text { puwa } 1423\end{array}$ \\
\hline 1394 & $\begin{array}{l}\text { stress, stresser 'chattel } \\
\text { seized in a distraint': It P } \\
\text { vno streSS capt p lez } \\
\text { scavegours in domo henr } \\
\text { Goodrych ob defect Camini } \\
\text { ibm iiijd }\end{array}$ & $\begin{array}{l}\text { OED stress } n . \mathrm{II} .10 . \mathrm{AN} \\
c 1440 ; M E D \text { stress(se (n.) } 4 . \\
1418\end{array}$ \\
\hline 1394 & $\begin{array}{l}\text { tyelscherdes 'tile-shards': It } \\
\text { P cariag de tyelscherdes de } \\
\text { sco Paulo iiijd }\end{array}$ & $\begin{array}{l}M E D \text { tile }(\mathrm{n} .(2)) \sim \text { scarthe } \\
1371 ; \text { OED tile-sherd, } n . \\
\text { OE + OE } 1527\end{array}$ \\
\hline 1394 & $\begin{array}{l}\text { rerdoose 'rere-dorse, } \\
\text { fireback': It vno Dawber P } \\
\text { factur Camini \& rerdoose \& } \\
\text { dawbur in domo Nichi } \\
\text { Carpent in grosso iijs iijd }\end{array}$ & $\begin{array}{l}O E D \text { reredos } n \text {. with } \\
\text { explicit comment re } 14^{\text {th }} \text { c. } \\
\text { mixed-language contexts; } \\
M E D \text { rere-dos(e (n.) } \\
\text { 'masonry backing for a } \\
\text { fireplace' AN + AN 1393; } \\
A N D \text { reredos }\end{array}$ \\
\hline 1395 & $\begin{array}{l}\text { kokyr (coker 1397)? : In } \\
p^{i} \text { mis P vno kokyr de vno } \\
\text { wynpipe P vna latina ibm } \\
\text { xijd (see sede) }\end{array}$ & $\begin{array}{l}\text { ?Cf } O E D \text { cock } n .{ }^{1} \text { IV.12.a. } \\
\text { 'spout' + -er; cf } M E D \text { coker } \\
\text { (n.) (b) 'covering for the } \\
\text { legs' (ie ?'lagging') }\end{array}$ \\
\hline 1395 & $\begin{array}{l}\text { hopys 'hoops': It vno couper } \\
\text { P hopys \& ope viijd }\end{array}$ & $\begin{array}{l}D M L B S \text { hopa } 31311 ; O E D \\
\text { hoop, } n .{ }^{l} \text { OE }\end{array}$ \\
\hline
\end{tabular}




\begin{tabular}{|c|c|c|}
\hline 1395 & $\begin{array}{l}\text { dormant 'sleeper, beam': In } \\
p^{i} \text { mis in meremio empt } P \\
\text { vna cama po j long dormant } \\
\& \text { iiij spares ijs vjd }\end{array}$ & $\begin{array}{l}D M L B S \text { dormantus } 1313 \\
\text { AN 'sleeper, 'horizontal } \\
\text { beam'; OED dormant } \\
\text { n.B.n.1.a. OE + OE ?1454; } \\
M E D \text { dorma(u)nt (adj. \& } \\
\text { n.) 2. 'beam' } 1411\end{array}$ \\
\hline 1395 & sparres 'spars, rafters' & $\begin{array}{l}D M L B S \text { sparra } 1211 ; \text { OED } \\
\text { spar, } n .{ }^{l} \mathrm{Gmc} c 1340\end{array}$ \\
\hline 1395 & $\begin{array}{l}\text { sixpenynayl: 'sixpenny- } \\
\text { nail' }\end{array}$ & $\begin{array}{l}\text { OED sixpenny, adj. and } n \text {. } \\
1426-7 ; \text { MED six (num.) } \\
\text { 1c.(d) } \sim \text { peni nail OE + OE + } \\
\text { OE } 1423\end{array}$ \\
\hline $\begin{array}{l}1395 \\
1403\end{array}$ & $\begin{array}{l}\text { wynpipe '?-pipe': In } p^{i} \text { mis } P \\
\text { vno kokyr de vno wynpipe } \\
\text { P vna latina ibm xijd; } \\
\text { Et in ij Wynpipes empt } P \\
\text { euesebord \& expen in dict } \\
\text { ospic pc le pipe vjd xjd }\end{array}$ & $? \mathrm{OE}+\mathrm{OE}$ \\
\hline 1396 & bordys 'boards' & $\begin{array}{l}D M L B S \text { borda } 1169 ; O E D \\
\text { board, } n \text {. OE }\end{array}$ \\
\hline 1396 & $\begin{array}{l}\text { seme: '?kind of beam' It ad } \\
\text { supponend vnu postem \& } \\
\text { vnu seme in la stabill }\end{array}$ & $\begin{array}{l}\text { ? DMLBS sagma/somera } \\
\text { 'breast-summer, horizontal } \\
\text { bar' 1296; ? cf } M E D \text { sem(e } \\
\text { (n.(2)) Churchwardens' } \\
\text { Accounts of Yatton, } \\
\text { Somerset, 1459-60: xxx } \\
\text { zeme of bordys, xij d. the } \\
\text { zeme }\end{array}$ \\
\hline 1396 & $\begin{array}{l}\text { raftys 'rafts, beams': It in } \\
\text { plankes \& raftys po la flor } \\
\text { xviijd }\end{array}$ & $\begin{array}{l}O E D \text { raft, } n .^{I} \text { ON } c 1330 ; \\
M E D \text { raft (n.) 'beam' } \\
\text { c1330(?c1300) }\end{array}$ \\
\hline 1396 & $\begin{array}{l}\text { longsappe: 'long sap-wood } \\
\text { laths': It in } \mathrm{j} C \& \text { dj lathes de } \\
\text { longsappe vijd ob }\end{array}$ & $\mathrm{OE}+\mathrm{OE}$ \\
\hline 1396 & playntille 'plain-tiles' & $\begin{array}{l}M E D \text { tile (n.(2))2.(b) 1377; } \\
O E D \text { plain tile, } n . \mathrm{AN}+\mathrm{OE} \\
1399-1400\end{array}$ \\
\hline 1396 & $\begin{array}{l}\text { stairschide 'stair-shide': It } \\
\text { ad supponend vnu postem } \\
\& \text { vnu seme in la stabill \& P } \\
\text { ij stapp P gadibz vsus } \\
\text { Garderobam \& vno } \\
\text { stairschide xiiijd }\end{array}$ & $\begin{array}{l}\text { MED; OED stair, } n . C 2 . \\
\text { stair-shide } \mathrm{OE}+\mathrm{OE} 1477- \\
9\end{array}$ \\
\hline 1397 & $\begin{array}{l}\text { fflaundichstiles 'flandrish- } \\
\text { tile': It in vjcfflaundichstiles } \\
\text { cu cariag iiijs vjd }\end{array}$ & $\begin{array}{l}\text { MED tile (n.(2))1.(b) } \\
\text { flanderischetylle } 1349 ; \\
\text { compound not in } O E D \text {, but } \\
\text { see Flanders, } n \text {.I.2.a. }\end{array}$ \\
\hline
\end{tabular}




\begin{tabular}{|c|c|c|}
\hline & & $\begin{array}{l}\text { Flanders tile AN + OE } \\
a 1399\end{array}$ \\
\hline 1397 & $\begin{array}{l}\text { standardes 'standards, } \\
\text { upright timbers or poles': It } \\
\text { in ij standardes xvjd }\end{array}$ & $\begin{array}{l}D M L B S \text { standardum } 1228 ; \\
O E D \text { standard, } n \text {. and } a d j \text {. } \\
\text { III.19.a. 'an upright timber' } \\
\text { AN } c 1450\end{array}$ \\
\hline 1397 & $\begin{array}{l}\text { storhous 'store-house': It in } \\
\text { ij lb sowdr sup le Storhous } \\
v d\end{array}$ & $\begin{array}{l}\text { MED stor(e (n.(1)) 4. (b) } \\
\text { hous AN + OE 1348; OED } \\
\text { storehouse, } n .1348 ;\end{array}$ \\
\hline 1398 & $\begin{array}{l}\text { shelle ?'hollowed wood': It } \\
\text { in j magn shelle de Elm ad } \\
\text { ponend sup j goter ibm } \\
\text { coram ostio dci hospic iiijd }\end{array}$ & $\begin{array}{l}\text { MED shel(le (n.) 6. (d) 'a } \\
\text { board or plank' } \\
1409(1338) ; \text { OED shell, } n \text {. } \\
\text { II. 'shell-shaped object; } \\
\text { something concave or } \\
\text { hollow' OE }\end{array}$ \\
\hline 1398 & shide 'shide' & $\begin{array}{l}\text { OED shide, } n \text {. 'piece of } \\
\text { timber' OE }\end{array}$ \\
\hline 1398 & rakkys 'racks' & $\begin{array}{l}D M L B S \text { racka } 1 \text { 'rack for } \\
\text { holding fodder for } \\
\text { livestock' } 1279 ; O E D \text { rack, } \\
n .{ }^{4} \text { 'rack holding animal } \\
\text { fodder' MDu/MLG } 1343-4\end{array}$ \\
\hline 1398 & $\begin{array}{l}\text { elm 'elm': In p } p^{i} \text { mis in iiijor } \\
\text { bordez de Elm empt P iij } \\
\text { ostiis ibm fiend de nouo xxd }\end{array}$ & $O E D$ elm, $n . \mathrm{OE}$ \\
\hline 1398 & sere 'bar, bolt' & $\begin{array}{l}D M L B S \text { sera 'bolt' c833; } \\
A N D \text { sere }^{1}\end{array}$ \\
\hline 1398 & $\begin{array}{l}\text { estate 'estate': In pimis in } \\
\text { vno doubar cu laborar suo } \\
\text { opanc ibm circa emendac } \\
\text { piet fract in estate p iij dies } \\
\text { cap p diem xijd }\end{array}$ & $\begin{array}{l}\text { OED estate, } n \text {. AN 12.a. } \\
\text { 'property' } 1563 ; M E D \text { estat } \\
\text { (n.) 21. 'property' } \\
\text { c1330(?c1300); AND estat } \\
\text { 6. 'lands, estate' }\end{array}$ \\
\hline 1398 & polynes 'pulleys' & $\begin{array}{l}\text { DMLBS pullanus } 1238 ; \\
\text { OED polaine, } n .^{l} \text { AN } 1295 ; \\
M E D \text { polein }(\mathrm{e}(\mathrm{n} .(1))(\mathrm{a}) \\
a 1350\end{array}$ \\
\hline 1398 & $\begin{array}{l}\text { shorthertlathes 'short } \\
\text { heart-lath': It in jC } \\
\text { shorthartlathes vijd }\end{array}$ & $\begin{array}{l}\text { Cf } D M L B S \text { hertlatha } 1333 \text {; } \\
\text { OED heart, } n \text {., int., and } a d v \text {. } \\
\text { C3.a. heart lath OE + OE + } \\
\text { OE } 1324 ; M E D \text { hart-lat (n.) } \\
\text { 'lath made from } \\
\text { heartwood' } 1332\end{array}$ \\
\hline 1398 & $\begin{array}{l}\text { saplogges 'sap-logs': It in } \\
\text { iiij saplogges empt \& expen } \\
\text { in supportag de ij Rakkys } \\
\text { ibm pc le saplog ijd viijd }\end{array}$ & $\mathrm{OE}+? \mathrm{AN}$ \\
\hline 1398 & $\begin{array}{l}\text { fagotstaues 'faggot-staves': } \\
\text { It in ix fagotstaues long } \\
\text { empt silit ad supportand }\end{array}$ & $\begin{array}{l}M E D \text { fagot (n.) (d) fagot } \\
\text { staf 'a pole for carrying } \\
\text { faggots' AN + OE } 1323\end{array}$ \\
\hline
\end{tabular}




\begin{tabular}{|c|c|c|}
\hline & $\begin{array}{l}\text { pdcm manger pc le staff ob } \\
\text { iiijd ob }\end{array}$ & \\
\hline 1399 & $\begin{array}{l}\text { latice 'lattice': In pimis inj } \\
\text { lattice empt \& fact de nouo } \\
\text { ad Camam in qua iacet } \\
\text { Receptor Ducis Lancastr } \\
\text { ibm videlt in Bordys iiijd; } \\
\text { latys }\end{array}$ & $\begin{array}{l}D M L B S \text { laticium } 1240 ; \\
O E D \text { lattice, } n . \text { AN } a 1382 ; \\
T L \text { lattis, subst. masc. xIII s. } \\
\text { 'garniture, ouvrage de } \\
\text { lattes' }\end{array}$ \\
\hline $\begin{array}{l}1400 \\
1401\end{array}$ & $\begin{array}{l}\text { gochenons 'gudgeons': It in } \\
\text { ij Gochenons de ferro P } j \\
\text { gapier ibm iiijd ; } \\
\text { Et in ij Goioynes de ferr } \\
\text { expendit in gapier pdce } \\
\text { coquine vjd }\end{array}$ & $\begin{array}{l}D M L B S \text { gojo } 2 \text { 'metal pivot } \\
\text { at end of axle' 1284; OED } \\
\text { gudgeon } n .{ }^{2} \text { 'pivot' AN } \\
1400 ; M E D \text { gojoun (n.(2)) } \\
\text { 1. (b) 'a ring or slot into } \\
\text { which the end of one of } \\
\text { the bars of a barred } \\
\text { window fits' 1354-5; } A N D \\
\text { gojoun } 2 \text { 'pin for securing } \\
\text { two parts together' }\end{array}$ \\
\hline 1400 & $\begin{array}{l}\text { couple 'couple': Et in ij pec } \\
\text { de querc expend in vno } \\
\text { couple fact de nouo in } \\
\text { emendacone vni }{ }^{9} \text { Came ibm } \\
\text { vjd }\end{array}$ & $\begin{array}{l}D M L B S 2 \text { copula 4a. } 1171 \text {; } \\
\text { OED couple, n. II. 8. 'one of } \\
\text { a pair of inclined rafters' } \\
\text { AN c600 }\end{array}$ \\
\hline 1400 & clampe 'clamp' & $\begin{array}{l}D M L B S \text { clampa 'metal } \\
\text { band' } 1279 ; O E D \text { clamp, } n .{ }^{\prime} \\
\text { ?MLG/MDu, ?* OE } a 1400\end{array}$ \\
\hline 1400 & $\begin{array}{l}t^{i} \text { rabe '?beam, ?roof-tree': } \\
\text { Et in j t'rabe de querc } \\
\text { expend in pdca Cama sup } \\
\text { stabulum ibm empt in } \\
\text { grosso vs iiijd }\end{array}$ & $\begin{array}{l}M E D \text { trave (n.) 'beam' } \\
\text { a1395; OED trave, n. } \\
\text { 'wooden beam' AN 1395; } \\
D M L B S \text { trab/s 'projecting } \\
\text { moulding' } 1465, \text { 'roof-tree' } \\
\text { c1595; TL trabe subst. fém } \\
\text { 'flagpole' } 17^{\text {th }} \text { c.; } A N D \\
\text { travure }\end{array}$ \\
\hline 1400 & $\begin{array}{l}\text { segestol 'sedge-stool': Et in } \\
\text { j segestol de nouo empt ad } \\
\text { vnam latrinam ibm iijd }\end{array}$ & $\begin{array}{l}\mathrm{AN}+\mathrm{OE} \text { 'privy'; cf } O E D \\
\text { siege, n.I.3.a. }\end{array}$ \\
\hline 1400 & $\begin{array}{l}\text { bechenelathes 'beechen- } \\
\text { laths': It in } C C \text { de } \\
\text { Bechenelathes } x d\end{array}$ & $\begin{array}{l}\text { OE + OE + OE; cf DMLBS } \\
\text { bechlatha } 1333 ; A N D \\
\text { bech }^{2} \text { bech lath } 1407-8\end{array}$ \\
\hline 1400 & resons 'raisings, planks' & $\begin{array}{l}\text { OED reason, } n .^{2} \text { AN } c 1330 \\
(1300) ; \text { Cf } D M L B S \\
\text { siderasenus }\end{array}$ \\
\hline 1400 & $\begin{array}{l}\text { resounpece 'raising-piece': } \\
\text { In pimis in ij gystes de } \\
\text { querc expendit in vna Cama } \\
\text { sup Pmptuar dci ten \& in } j \\
\text { resounpece de querc } \\
\text { expend in alia Cama sup }\end{array}$ & $\begin{array}{l}\text { OED raising-piece, } n .^{1} \mathrm{OE}+ \\
\text { AN } 1286 ; M E D \text { rasen (n.) } \\
\text { (a) } \sim \text { pece } 1286\end{array}$ \\
\hline
\end{tabular}




\begin{tabular}{|c|c|c|}
\hline & vnu stabulum ibm & \\
\hline 1401 & $\begin{array}{l}\text { traunsouns 'transoms': Et } \\
\text { in ij qarts de querc } P \\
\text { traunsouns expendit in } \\
\text { gotes ibm iijd }\end{array}$ & $\begin{array}{l}\text { OED transom, } n \text {. 'cross- } \\
\text { beam' ?L 1487-8; } M E D \\
\text { traunsom (n.) 1347-50 }\end{array}$ \\
\hline $\begin{array}{l}1400 \\
1401\end{array}$ & $\begin{array}{l}\text { couplefeet ?'couple-feet': It } \\
\text { in brodeheuedenaill P } \\
\text { couplefeet \& euesebord iijd } \\
\text { ob; } \\
\text { Et in iij longe couplesfet } \\
\text { empt ad emendand j shedde } \\
\text { ibm iijd }\end{array}$ & ?AN + OE (cf couple) \\
\hline 1401 & $\begin{array}{l}\text { longe postes 'long posts': Et } \\
\text { in iij longe postes de querc } \\
\text { empt \& expend in pdcis } \\
\text { opibz pc le poste viijd ijs }\end{array}$ & $\mathrm{OE}+\mathrm{OE}$ \\
\hline 1401 & $\begin{array}{l}\text { shortpostes 'short posts': } \\
\text { Et in iij shortpostes de } \\
\text { querc expend ibm pc le } \\
\text { poste iiijd xijd }\end{array}$ & $\mathrm{OE}+\mathrm{OE}$ \\
\hline 1402 & $\begin{array}{l}\text { zylehous 'gile-house': Et in } \\
\text { vn somer de querc empt \& } \\
\text { expend in le zylehous ibm } \\
\text { xvjd }\end{array}$ & $\begin{array}{l}\text { OED gyle, } n \text {. gyle-house } \\
\text { MDu + OE ?1333-4; MED } \\
\text { gil(e (n.(2))(c) hous } \\
1423 ; \text { cf } D M L B S \text { gylefatta } \\
1266\end{array}$ \\
\hline 1402 & $\begin{array}{l}\text { corovn 'crown': Et in j } \\
\text { Corovn de ferr expendit in } \\
\text { dco louere iiijd }\end{array}$ & $\begin{array}{l}D M L B S \text { corona CL; OED } \\
\text { crown, } n \text {. II. 8.a. 'circular } \\
\text { ornament' L a1325 }\end{array}$ \\
\hline 1402 & $\begin{array}{l}\text { somer 'horizontal bearing } \\
\text { beam': Et in vn somer de } \\
\text { querc empt \& expend in le } \\
\text { zylehous ibm xvjd }\end{array}$ & $\begin{array}{l}\text { DMLBS sagma/somerius } \\
\text { 'breast-summer', horizontal } \\
\text { bar 1296; OED summer } n^{2} \\
\text { II.2.b. AN 1359-60; AND } \\
\text { somer ' 'horizontal beam' }\end{array}$ \\
\hline 1402 & $\begin{array}{l}\text { palice 'fence of pales, } \\
\text { palisade' }\end{array}$ & $\begin{array}{l}D M L B S \text { palicium } 1091 ; T L \\
\text { palis 'palissade' } 1091 ; \\
O E D \text { palis, } n . \text { AN } c 1400 \\
(? c 1390)\end{array}$ \\
\hline 1402 & peire 'pair' & $\begin{array}{l}D M L B S \text { paria } 1212 ; O E D \\
\text { pair, } n .{ }^{l} \text { AN } c 1300\end{array}$ \\
\hline 1402 & $\begin{array}{l}\text { trapdore 'trap-door': Et in } j \\
\text { cerur expendit in j trapdore } \\
\text { vjd }\end{array}$ & $\begin{array}{l}\text { OED trap-door, } n . \mathrm{OE}+\mathrm{OE} \\
c 1374 ; M E D \text { trappe-dore } \\
\text { (n.) } 1423-4\end{array}$ \\
\hline 1402 & $\begin{array}{l}\text { heyhousdore 'hay-house- } \\
\text { door': Et in j peire heng } \\
\text { expen sup j heyehousdore } \\
\text { ibm iijd }\end{array}$ & $\mathrm{OE}+\mathrm{OE}+\mathrm{OE}$ \\
\hline 1403 & $\begin{array}{l}\text { cacche 'catch': Et in iij clau } \\
\text { cu j lacch \& cacche de ferr } \\
\text { expen ibm vjd ob }\end{array}$ & $\begin{array}{l}\text { DMLBS } 2 \text { cacha 1419; MED } \\
\text { cacche (n.) (a) 1399; OED } \\
\text { catch, } n .^{1} 10 . \text { 'catch of a }\end{array}$ \\
\hline
\end{tabular}




\begin{tabular}{|c|c|c|}
\hline & & $\begin{array}{l}\text { door, etc' AN 1520; AND } \\
\text { cache }^{2}\end{array}$ \\
\hline 1404 & $\begin{array}{l}\text { rigoiles 'gutters': It in } \\
\text { rigoiles \& \& (sic) railles } P \\
\text { fenestr ibm viijd }\end{array}$ & $\begin{array}{l}D M L B S \text { rigolus } 1292 \\
\text { 'channel, groove'; } T L \\
\text { 'partie d'un fossé où coule } \\
\text { l'eau' c. } 1210 ; \text {; } O E D \text { rigol, } \\
\text { n.3.a. 'gutter' AN } 1658\end{array}$ \\
\hline 1404 & $\begin{array}{l}\text { oylet 'eyed portion of } \\
\text { hinge', 'spyhole' }\end{array}$ & $\begin{array}{l}D M L B S \text { oillettus } 1384 ; \\
\text { OED oillet, } n . \text { AN } 1333 ; \\
M E D \text { oilet (n.) 3. (b) } 1447 \text {; } \\
\text { AND oillet }\end{array}$ \\
\hline 1404 & $\begin{array}{l}\text { stoklokkes 'stock-locks': In } \\
\text { iij stoklokkes P diusis Camis } \\
\text { ibm xviijd }\end{array}$ & $\begin{array}{l}\text { OED stock-lock, } n . \text { OE + OE } \\
1365-6 ; M E D \text { stok } \\
\text { (n.(1))3c.(a) lok 'a lock } \\
\text { enclosed in a wooden case' } \\
1365-6\end{array}$ \\
\hline 1404 & $\begin{array}{l}\text { dorplate 'door-plate': It P } \\
\text { vno dorplate P aula ibm \& } \\
\text { alioO neccaioO vjs viijd }\end{array}$ & $\mathrm{OE}+\mathrm{AN}$ \\
\hline 1405 & $\begin{array}{l}\text { doggeys 'dogs, wainscot': It } \\
\text { in vj Punchones \& ij peciis } \\
\text { voc doggeys xijd }\end{array}$ & $\begin{array}{l}D M L B S \text { doga 'wainscot' } \\
1472 ; \text { cf } O E D \text { dog, } n .{ }^{l} \\
\text { III. Specialized uses, } \\
\text { denoting various } \\
\text { mechanical devices for } \\
\text { gripping or holding }\end{array}$ \\
\hline 1405 & $\begin{array}{l}\text { caue 'cave, pit': It ij laborat } \\
\text { fodent vnu Caue de nouo P } \\
\text { lat'na coi ibm \& cariand } \\
\text { finm p xiij dies cap p die vjd } \\
\text { xiijs }\end{array}$ & $\begin{array}{l}D M L B S \text { cavus } 2 \mathrm{~b} . \text { 'cellar' } \\
\mathrm{CL} ; O E D \text { cave, } n .{ }^{1} \mathrm{AN} ; \\
M E D \text { cave (n.(1))2. 'pit' } \\
\text { c1330 }\end{array}$ \\
\hline 1405 & $\begin{array}{l}\text { copon 'couperon, coping, } \\
\text { pinnacle' }\end{array}$ & $\begin{array}{l}\text { DMLBS copero 'toppings' } \\
1209 ; \text { OED coperoun, } n \text {. AN } \\
c 1400(? c 1390) ; A N D \\
\text { couperon } 2 ; M E D \text { coperoun } \\
\text { (n.) } 1395\end{array}$ \\
\hline 1405 & $\begin{array}{l}\text { fframantes 'roof-timbers': } \\
\text { In primis in duobz } \\
\text { Carpentar opant ibm p vj } \\
\text { dies ad repand duas camas } \\
\text { \& vna coq } \text { na et fframantes } \\
\text { xvj copulas ibm quislt cap p } \\
\text { die vijd Sma vijs }\end{array}$ & $\begin{array}{l}\text { AND framante 'roof } \\
\text { (timbers), ceiling' AN } \\
c 1175\end{array}$ \\
\hline 1405 & $\begin{array}{l}\text { botys, bote 'boatload': It in } \\
\text { iiij Botys empts de calc } P \\
\text { Celar in dco ten faciend pc } \\
\text { Bote xiijs iiijd liijs iiijd It in } \\
\text { al Bote empt de calc pc xijs } \\
\text { Itm } P \text { cariag dict calc pc le } \\
\text { Bote iiijs xxs Et } P \text { wharffage }\end{array}$ & $\begin{array}{l}A N D \text { bot }^{2} \text { 'boatload' (un } \\
\text { bote de ragge) AN 1426-7; } \\
\text { cf } O E D \text { boat, } n .{ }^{l}\end{array}$ \\
\hline
\end{tabular}




\begin{tabular}{|l|l|l|}
\hline 1405 & P eisdm iijs iiijd & \\
& $\begin{array}{l}\text { wymbeme '? -beam': It in } \\
\text { vno Rafto empt cuj } \\
\text { wymbeme P } \text { copula vd }\end{array}$ & ? + OE \\
\hline 1405 & $\begin{array}{l}\text { gutters 'gutters': It } j \\
\text { Tegulator opant ibm } \\
\text { adconseruand tegul } \\
\text { remouend plumbu de } \\
\text { Gutters } p \text { iij dies cap p die } \\
\text { viijd ijs }\end{array}$ & $\begin{array}{l}\text { DMLBS guttera } 11 . . ; T L \\
\text { gotiere c. } 1145 ; \text { OED gutter, } \\
\text { n. AN a1300; AND gutere }\end{array}$ \\
& \\
\hline
\end{tabular}

\section{References}

\section{Manuscripts}

London Metropolitan Archive, CLC/313/L/D/001/MS25125/001, 003, 005, 007 8, 012, 014-5, 018-20, 022, 024-6, 028-36, 038-42, 044-6, Dean \& Chapter of St Paul's Cathedral, London, Rental \& Accounts (rolls not included yielded no new vocabulary).

\section{Dictionaries}

$A N D=$ Anglo-Norman Dictionary. Online at www.anglo-norman.net.

DMLBS = Dictionary of Medieval Latin from British Sources. Latham, Ronald E., David R. Howlett, et al., eds. 1975-. Oxford: The British Academy and Oxford University Press.

$M E D=$ Middle English Dictionary. Ann Arbor: University of Michigan Press. Online at http://quod.lib.umich.edu/m/med/.

$O E D=$ Oxford English Dictionary. Online at http://www.oed.com.

Tobler, A. \& E. Lommatzsch (1969). Altfranzösisches Wörterbuch. Wiesbaden: Franz Steiner.

http://atilf.atilf.fr/dendien/scripts/tlfiv4/showps.exe?p=combi.htm;java=no

\section{Printed Works}

Alcolado Carnicero, José Miguel. 2013. Social Networks and Mixed-Language Business Writing: Latin/French/English in the Wardens' Accounts of the Mercers' Company of London, 1390-1464. Unpublished PhD thesis: University of CastillaLa Mancha.

Howlett, David. 1997. "A polyglot glossary of the twelfth century". In: Gregory Stewart and David A. Trotter (eds.). De Mot en Mot. Aspects of Medieval Linguistics. Essays in Honour of William Rothwell. Cardiff: University of Wales Press. 81-91. 
Ingham, Richard (ed.) 2010. The Anglo-Norman Language and its Contexts. Woodbridge: Boydell and Brewer.

Ingham, Richard. 2011. "Code-switching in the later medieval English lay subsidy rolls." Herbert Schendl and Laura Wright, eds. 95-114.

Ingham, Richard. 2012. The Transmission of Anglo-Norman: Language History and Language Aquisition. Amsterdam: John Benjamins.

Ingham, Richard. 2013. "Language-mixing in medieval Latin documents: vernacular articles and nouns." In Judith A. Jefferson and Ad Putter (eds.) Multilingualism in Medieval Britain 1100-1500: Sources and analysis. Turnhout: Brepols. 105-121.

Ingham, Richard. In press. "Medieval Bilingualism: Perspectives from Codeswitching and from Language Choice". In Päivi Pahta, Janne Skaffari and Laura Wright (eds). Mouton.

Rothwell, William. 2008. 'Anglo-French in rural England in the later thirteenth century: Walter of Bibbesworth's Tretiz and the Agricultural Treatises.' Vox Romanica, 68, 100-32.

Rothwell, William. 2009. "Soil and toil: English and French in the English countryside during the later Middle Ages". English Studies, 90, 379-402.

Rothwell, William. 2012. "Language and society in post-Conquest England: farming and fishing." Modern Language Review, 107, 389-407.

Salzman, L. F. 1952 [1997] Building in England Down to 1540 A Documentary History. Oxford: Clarendon.

Schendl, Herbert. 2011. "Beyond boundaries: Code-switching in the leases of Oswald of Worcester". 2011. Herbert Schendl and Laura Wright, eds. 47-94.

Schendl, Herbert and Laura Wright, eds. 2011. Code-switching in Early English. Berlin: Mouton.

Smith, Joseph. 1898-1905. English Dialect Dictionary. Oxford: Oxford University Press.

De Schepper, Tom and Stam, Nike. Forthcoming. "The influence of visual diamorphs in two medieval Irish corpora".

Trotter, David. 2010. "Bridging the gap: the (socio)linguistic evidence of some medieval English bridge accounts". In Richard Ingham, ed. 52-62.

Trotter, David. 2014a. "Why are there so few French place-names in England?" English Today, 30 (2), 39-42.

Trotter, David. 2014b. "Deinz Certeins Boundes: Where does Anglo-Norman Begin and End?" Romance Philology 67, 139-177. 
Wright, Laura. 1995. "A Hypothesis on the Structure of Macaronic Business Writing." Jacek Fisiak (ed.), Medieval Dialectology. Trends in Linguistics Studies and Monographs 79. Berlin: Mouton de Gruyter. 309-321.

Wright, Laura. 1995. "Middle English -ende and -ing: a possible route to grammaticalization." Jacek Fisiak, (ed.), Linguistic Change under Contact Conditions. Trends in Linguistics Studies and Monographs 81. Berlin: Mouton de Gruyter. 365-382.

Wright, Laura. 1996. Sources of London English: Medieval Thames Vocabulary. Clarendon: Oxford University Press.

Wright, Laura. 1998. "Mixed-language Business Writing: Five Hundred Years of Codeswitching". In Language Change: Advances in Historical Sociolinguistics, Ernst Håkon Jahr (ed.) Trends in Linguistics Studies and Monographs 114, 99118. Berlin: Mouton de Gruyter.

Wright, Laura. 2002. "Code-intermediate phenomena in medieval mixedlanguage business texts" in Language Sciences 24, 471-489. Amsterdam: Elsevier.

Wright, Laura. 2005. "Medieval Mixed-Language Business Texts and the Rise of Standard English." Opening Windows on Texts and Discourses of the Past. Edited by Janne Skaffari, Matti Peikola, Ruth Carroll, Risto Hiltunen and Brita Wårvik. Pragmatics and Beyond New Series 134. Amsterdam: John Benjamins. 381-399.

Wright, Laura. 2010. "A pilot study on the singular definite articles le and la in fifteenth-century London mixed-language business writing". In Richard Ingham (ed). The Anglo-Norman Languge and its Contexts. York: York Medieval Press and The Boydell Press, 130-142.

Wright, Laura. 2012. "On variation and change in London medieval mixedlanguage business documents." In Merja Stenroos, Martti Mäkinen and Inge Særheim (eds.), Language Contact and Development around the North Sea. Amsterdam/Philadelphia: John Benjamins, 99-115.

Wright, Laura. 2013. "On historical language dictionaries and language boundaries". Liliana Sikorska and Marcin Krygier (eds.) Evur Happie \& Glorious, ffor I hafe at Will Grete Riches. Medieval English Mirror 9, 11-26.

Wright, Laura. In press. "A Multilingual Approach to the History of Standard English". In Pahta, Paivi, Janne Skaffari and Laura Wright (eds.). Mouton. 